\title{
Injection Heating Scenarios for TNS
}

\author{
J. A. Rome \\ Y-K. M. Peng \\ J. A. Holmes
}

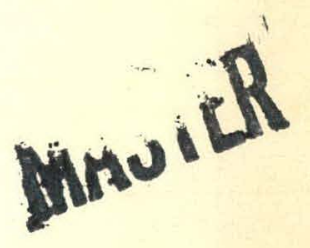

\section{OAK RIDGE NATIONAL LABORATORY}

OPERATED BY UNION CARBIDE CORPORATION FOR THE ENERGY RESEARCH AND DEVELOPMENT ADMINISTRATION 


\section{DISCLAIMER}

This report was prepared as an account of work sponsored by an agency of the United States Government. Neither the United States Government nor any agency Thereof, nor any of their employees, makes any warranty, express or implied, or assumes any legal liability or responsibility for the accuracy, completeness, or usefulness of any information, apparatus, product, or process disclosed, or represents that its use would not infringe privately owned rights. Reference herein to any specific commercial product, process, or service by trade name, trademark, manufacturer, or otherwise does not necessarily constitute or imply its endorsement, recommendation, or favoring by the United States Government or any agency thereof. The views and opinions of authors expressed herein do not necessarily state or reflect those of the United States Government or any agency thereof. 


\section{DISCLAIMER}

Portions of this document may be illegible in electronic image products. Images are produced from the best available original document. 
Printed in the United States of America. Available from National Technical Information Service

U.S. Department of Commerce 5285 Port Royal Road, Springfield, Virginia 22161

Price: Printed Copy $\$ 3.50$; Microfiche $\$ 3.00$

This report was prepared as an account of work sponsored by the United States Government. Neither the United States nor the Energy Research and Development Administration/United States Nuclear Regulatory Commission, nor any of their employees, nor any of their contractors, subcontractors, or their employees, makes any warranty, express or implied, or assumes any legal liability or responsibility for the accuracy, completeness or usefulness of any information, apparatus, product or process disclosed, or represents that its use would not infringe privately owned rights. 
ORNL/TM-5931

Contract No. W-7405-eng-26

Fusion Energy Division

INJECTION HEATING SCENARIOS FOR TNS

J. A. Rome, Y-K. M. Peng, J. A. Holmes

NOTICE This document contains information of preliminary nature. It is subject to revision or correction and therefore does not represent a final report.

Date Published: July 1977

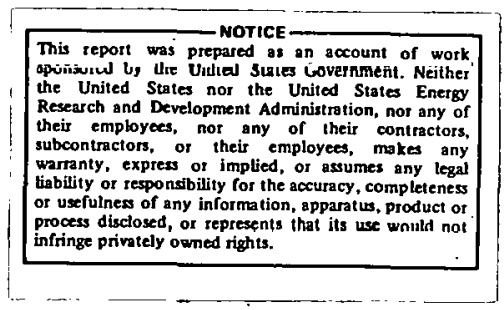

Prepared by the

OAK RIDGE NATIONAL LABORATORY

Oak Ridge, Tennessee 37830

operated by

UNION CARBIDE CORPORATION

for the

ENERGY RESEARCH AND DEVELOPMENT ADMINISTRATION 
THIS PAGE

\section{WAS INTENTIONALLY LEFT BLANK}




\begin{abstract}
Neutral beam injection heating is a prime contender for heating TNS. However, injection into a full bore high density plasma during start-up will not give adequate beam penetration even with deuteron energies up to $300 \mathrm{keV}$ and $z_{\text {eff }}<1.5$. But low density start-up may be feasible with deuteron energies of $\sim 150 \mathrm{keV}$ if advantage is taken of the $\alpha$-heating and flux surface shifts which occur when $\beta$ is increased.
\end{abstract}




\section{INTRODUCTION}

Neutral beam injection heating is the most technically advanced and experimentally proven form of auxiliary tokamak heating. As such, it is a prime contender for heating TNS (The Next Step). Although existing injection experiments have been uniformly successful, these injected tokamaks are sma11, low density devices and are not representative of TNS. In TNS, the major problem is a lack of beam penetration. We attempt to scope the problem and outline possible strategies for overcoming it.

A first response to the penetration problem might be to raise the injection energy, but this entails severe penalties in injection efficiency. As the deuteron energy is increased beyond $200 \mathrm{keV}$, the efficiency of neutralizing the fast ions decreases to below $15 \%$. With such a low efficiency, direct conversion would be necessary in a practical reactor and a large investment in injectors, power supplies, and other hardware would be required. Indeed, one may wonder whether there would be enough physical access on the machine for the requisite number of injectors!

Above $200 \mathrm{keV}$, negative ion sources have a much higher efficiency and appear attractive. However, this technology is in its infancy and a massive development program would be required if negative ion sources were to be used.

Thus, we would like to obtain an injection scenario that would successfully heat TNS with deuteron beams of less than $200 \mathrm{keV}$ energy.

2. FULL BORE, HIGH DENSITY START-UP

The straightforward approach to heating TNS is to try injection into the full bore, high density TNS plasma. As a base case around which we varied parameters, we used the following values.

$$
\begin{array}{ll}
\mathrm{R}_{\mathrm{o}}=5 \mathrm{~m} & \mathrm{I}=4.3 \mathrm{MA} \text { (parabolic) } \\
\mathrm{a}=1.25 \mathrm{~m} & \mathrm{n}_{\mathrm{e}}=\mathrm{n}_{\mathrm{p}}=3 \times 10^{14}\left[1-(\mathrm{r} / \mathrm{a})^{2}\right]^{2} \\
\mathrm{z}_{\text {eff }}=1 & \mathrm{E}_{\text {deuteron }}=300 \mathrm{keV}
\end{array}
$$

Injection angle $=16^{\circ}$ from perpendicular (coinjection)

Our present beam deposition code integrates around the actual fast ion orbits but is restricted to circular concentric flux surfaces. Thus, the D-shaped nature of TNS was ignored. 
Figure 1 shows the effect of lowering injection energy below $300 \mathrm{keV}$. The generally accepted criterion of a "flat $H(r)$ profile" for adequate beam penetration would imply that at least $250-\mathrm{keV}$ deuteron energy would be needed. However, a better criterion is that the ratio of the $H(r)$ profile to the density profile should be flat, because it is the energy delivered per particle that counts. This requires an even stronger peaking of $H(r)$ and with this criterion, even $300-\mathrm{keV}$ energies are marginal.

Things deteriorate rapidly when $z_{\text {eff }}$ is increased, as shown in Fig. 2. Although our calculation enhanced only the proton impact ionization cross section by $z_{\text {off }}$ and ignored the enhancement of the charge exchange cross section, it is clear that almost any impurity level is intolerable.

Ut course, lowering the plasma density (Fig. 3) improves penetration: $\mathrm{H}(\mathrm{r})$ is strongly peaked at a central density of $1 \times 10^{14} \mathrm{~cm}^{-3}$. Penetration is already bad at a density of $4 \times 10^{14} \mathrm{~cm}^{-3}$.

Finally, in Fig. 4 we vary the injection angle because a more nearly perpendicular (smaller) angle decreases the distance to the magnetic axis. This angle can only be decreased to about $12^{\circ}$ from perpendicular in order to avoid trapping of the beam ions in the ripples of the toroidal magnetic field. An angle of $16^{\circ}$ may not be sufficiently parallel because the particles need only scatter $4^{\circ}$ in pitch angle to reach the ripple trapping region. Thus, the largest possible angle should probably be chosen, consistent with coil clearances.

The net result of these brief surveys is dismal: it is very difficult to penetrate a full bore, full density TNS plasma even at an energy of $300 \mathrm{keV}$.

\section{FULL BORE, LOW DENSITY START-UP}

The scenario of Sect. 2 is unrealistic because a tokamak the size of TNS will not operate at such a high density without injection, at least if the scaling law $\mathrm{n}_{\mathrm{e}} \sim \mathrm{B}_{\mathrm{T}} / \mathrm{R}_{\mathrm{o}}$ can be believed. Thus, TNS will have to start at much lower densities, i.e., $\mathrm{n}_{\mathrm{e}}(0) \sim 2 \times 10^{13} \mathrm{~cm}^{-3}$. Because the density is lower, we may also consider a lower energy beam and still be assured of penetration. 


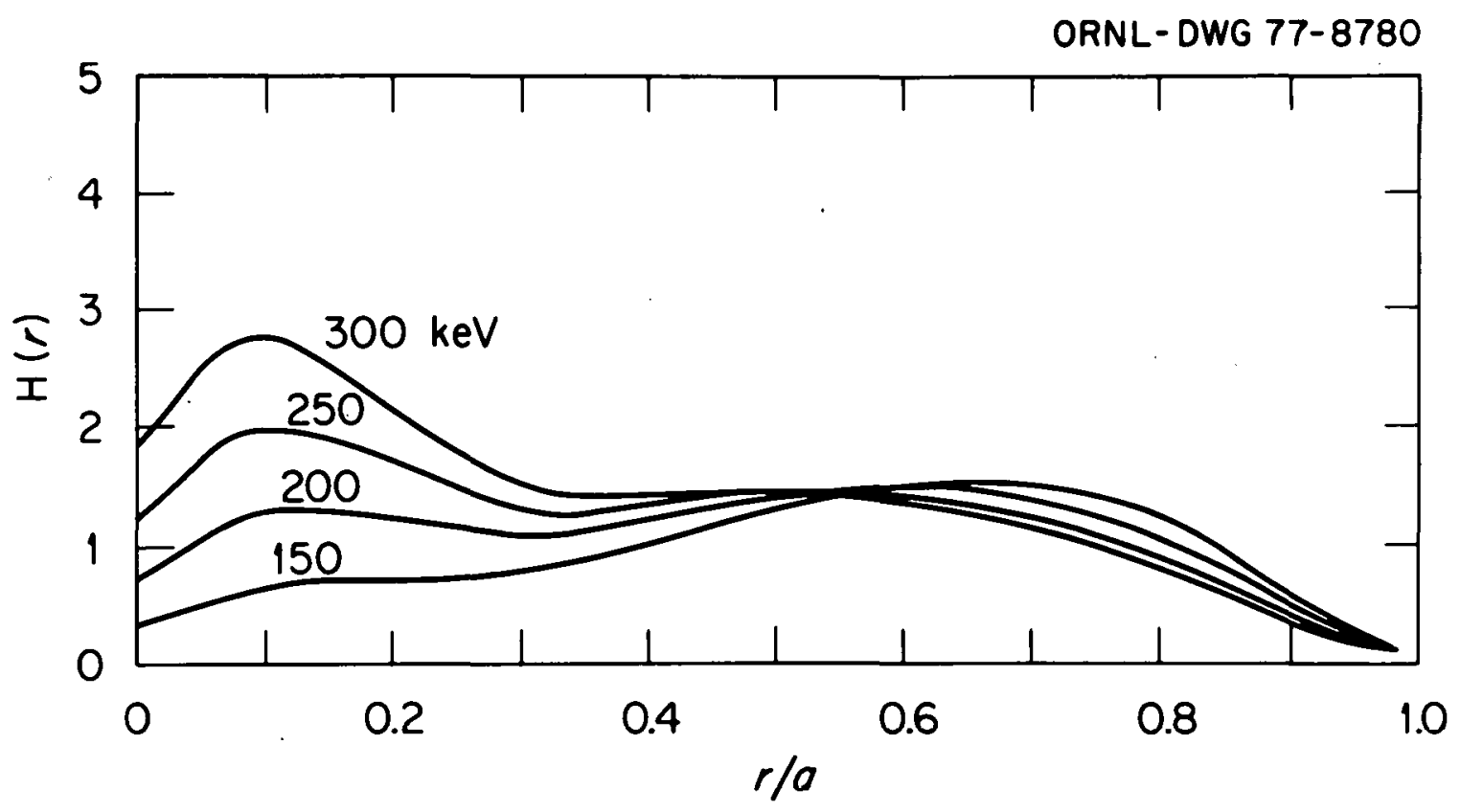

Fig. 1. The effect of deuteron energy on penetration for near perpendicular injection.

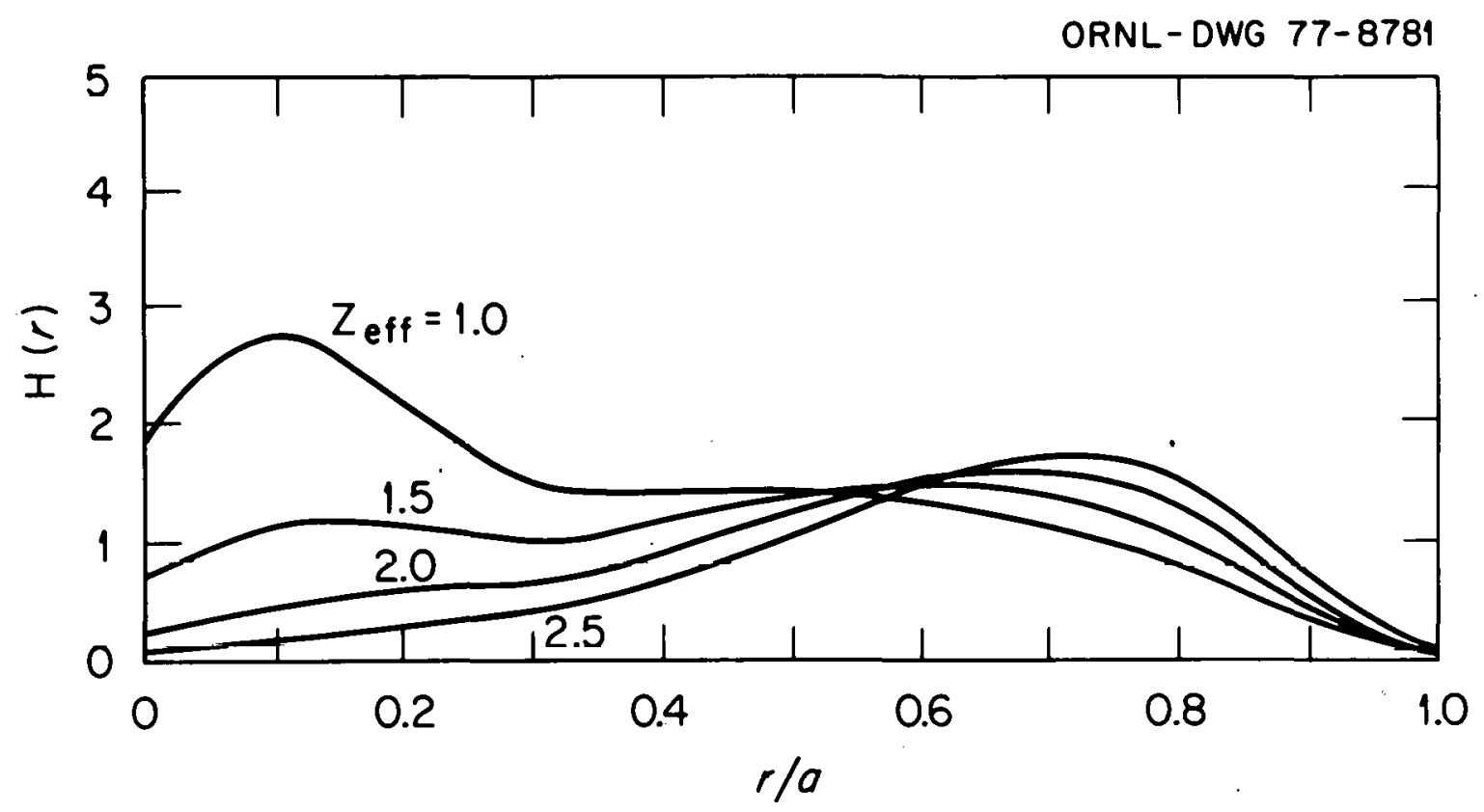

FAg. 2, The effect of impurities on beam penetration for near perpendicular injection. 


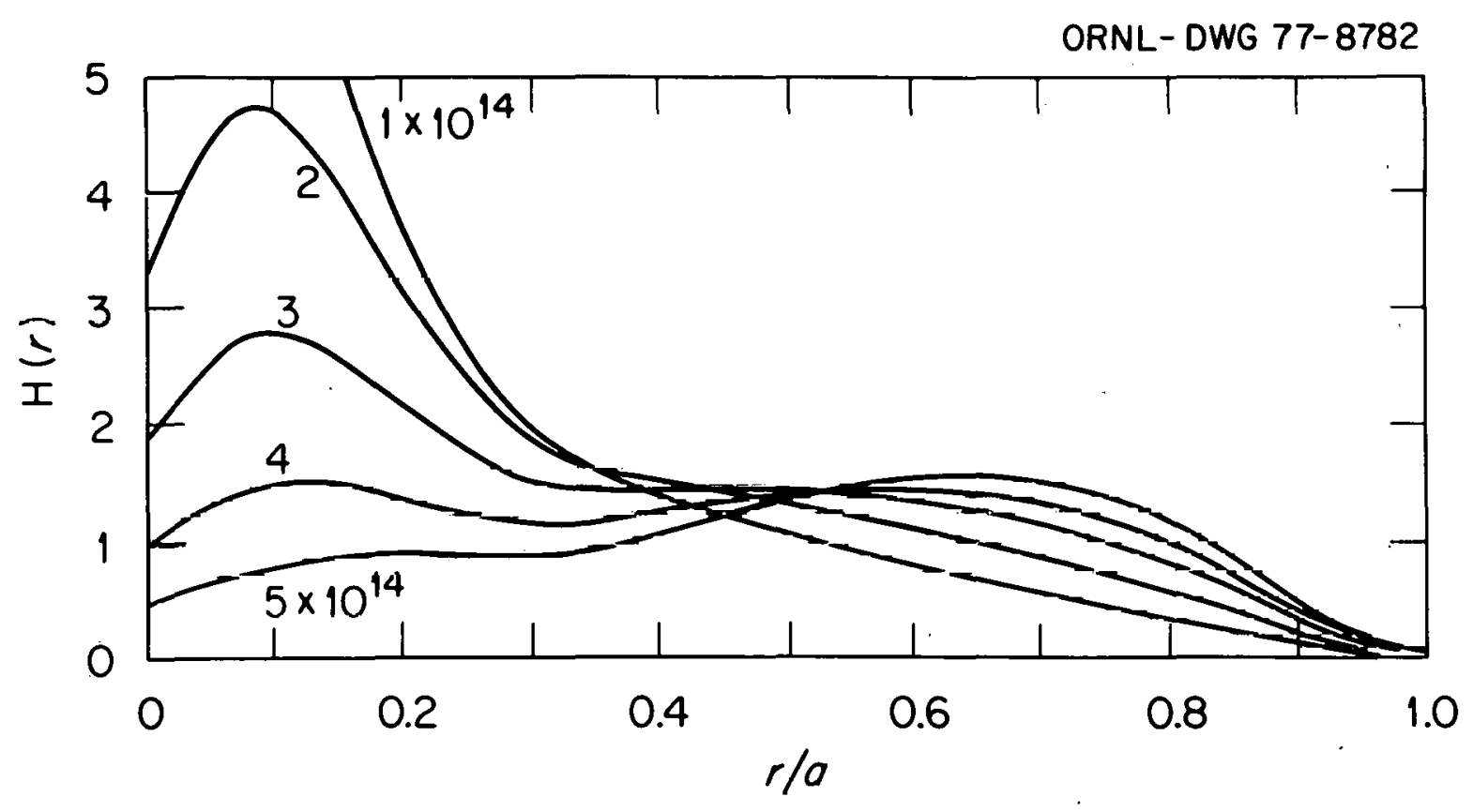

Fig. 3. The effect of central electron density on beam penetration for near perpendicular injection.

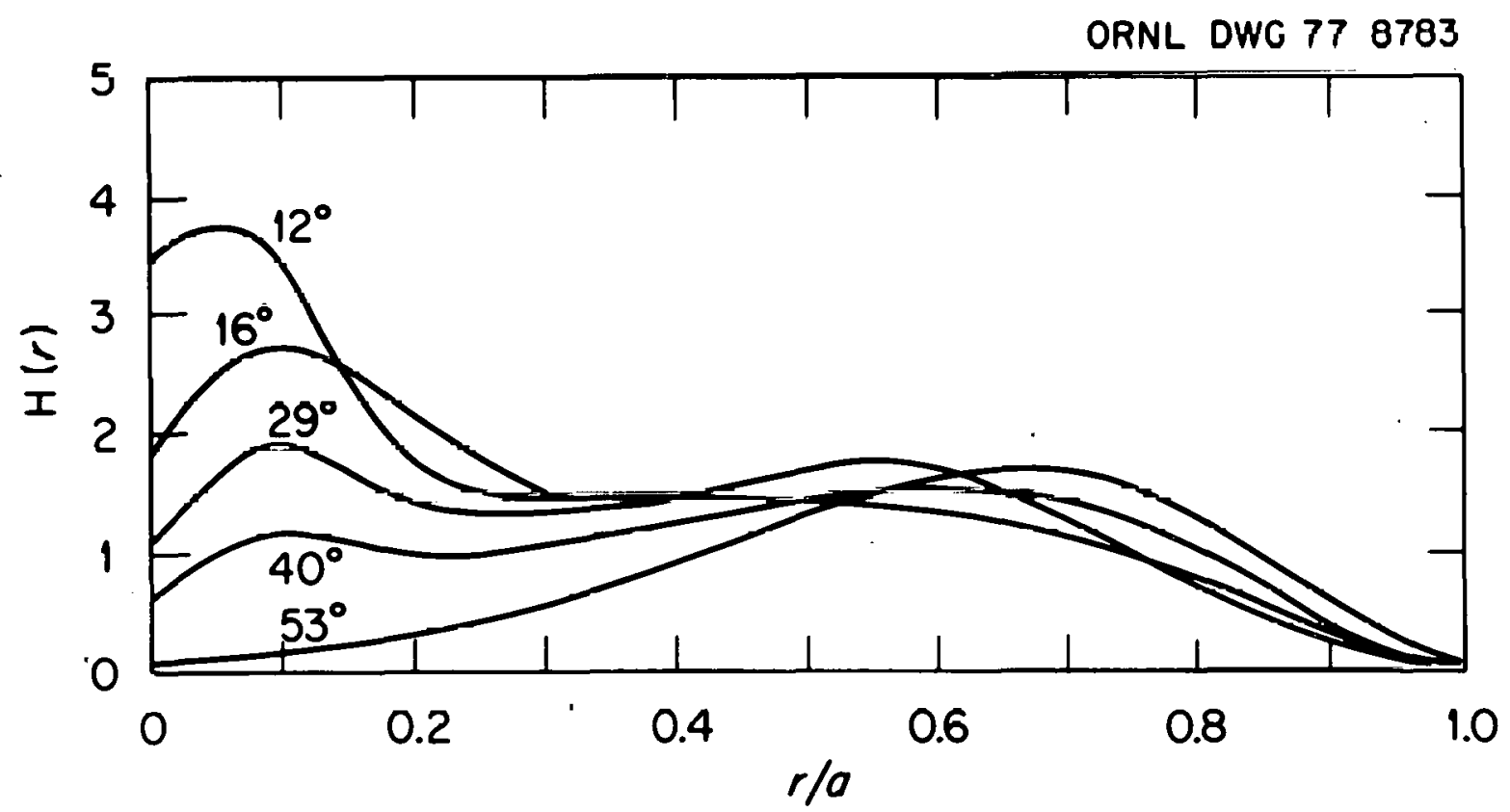

Fig. 4. The effect of injection angle on beam penetration. 
For example, in Fig. 5(a), we show that a 150-keV deuteron beam can easily penetrate a $5 \times 10^{13} \mathrm{~cm}^{-3}$ full bore TNS plasma and deposit most of its energy in the central region. Thus, we consider injecting into such a low $\beta$, low density plasma. As the plasma heats up, we increase the density by gas puffing and/or by pellet injection. Simultaneously, $B$ is increasing in a flux conserving manner. As this occurs, the flux surfaces shift outward so that the penetration distance to the magnetic axis decreases. As $\bar{\beta}$ approaches $3 \%$, fusion reactions begin to occur near the magnetic axis with the resulting $\alpha$-particles heating the central core of the plasma. This is an important effect because by now the density has increased to a point where beam penetration is becoming marginal and most beam heating occurs away from the core region.

In the final state, $\bar{\beta}+15 \%, \mathrm{n}_{\mathrm{e}}(0) \simeq 4 \times 10^{14} \mathrm{~cm}^{-3}$, and the magnetic axis has shifted outward to $560 \mathrm{~cm}$. Figure $5(\mathrm{~b})$ shows beam deposition in this case where we have assumed a circular plasma with $R_{0}=560 \mathrm{~cm}$ and $a=65 \mathrm{~cm}$. The actual $\mathrm{H}(\mathrm{r})$ would be lower than this because the actual $\dot{D}$-shaped volume is greater than we assumed.

Thus, it appears that utilizing a low density start-up and taking advantage of $\alpha$-particle heating and flux surface shifts will allow $150-\mathrm{keV}$ deuteron beams to have adequate penetration. Also, since the slowing down time is shorter for lower energy beams, the plasma will be heated more quickly and will be able to conserve flux more easily.

\section{INTEGRATED SCENARIO}

To test the plausibility of the above scenario, we employed a simplified one-dimensional flux coordinate transport code together with the flux conserving tokamak (FCT) equilibrium solver to see what would happen in a self-consistent manner. We assumed empirical scaling and arbitrarily increased the density as time progressed. A net heating of $50 \mathrm{MW}$ from 150-keV deuteron injectors was used to start the heating process.

Figure 6 shows the temperature and density profiles along the equator as $\beta$ is increased. The initially symmetric profiles become progressively shifted outwards. In Fig. 7, the $\alpha$-particle heating profiles are shown 

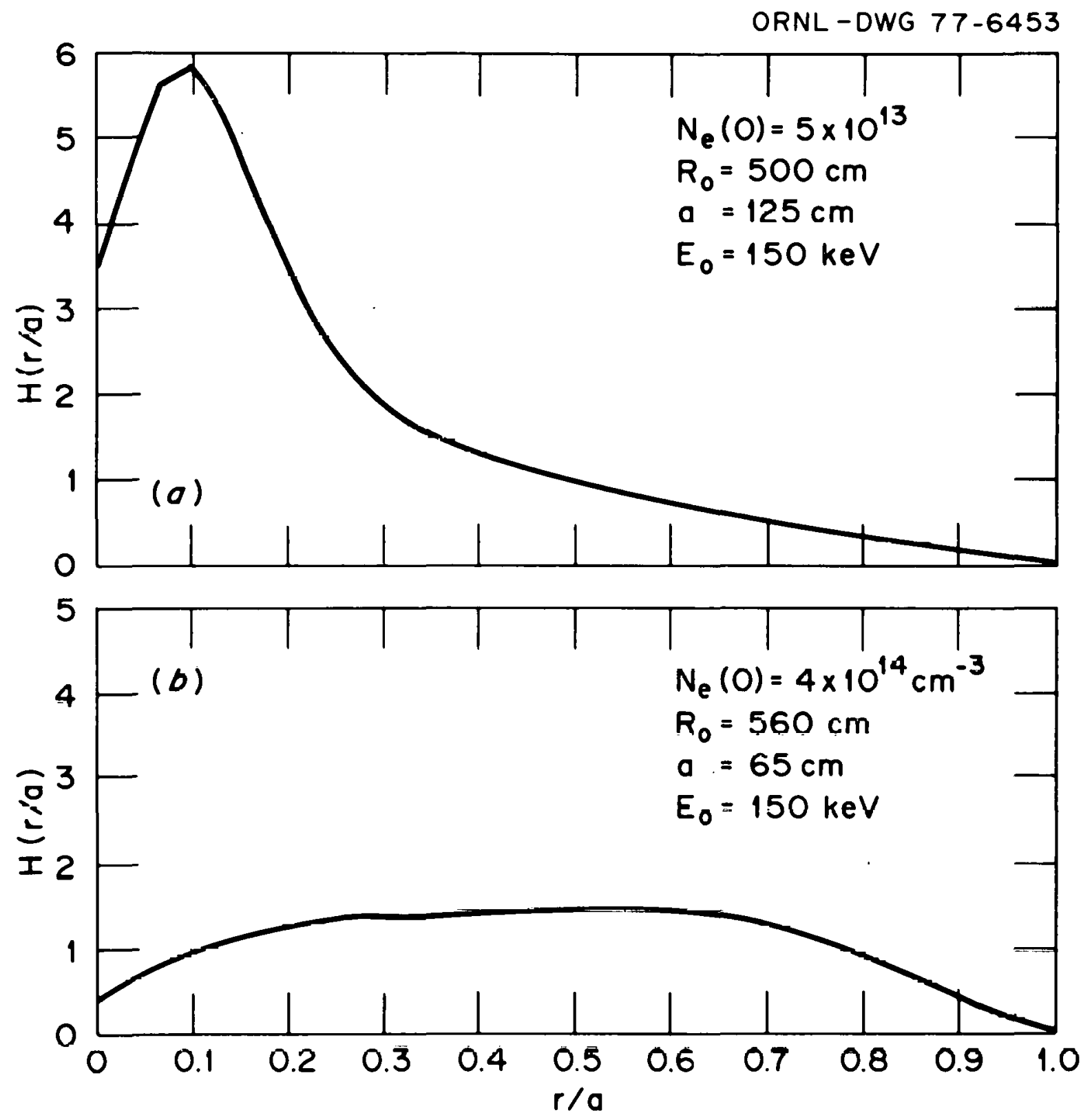

Fig. 5. The flux surface shifts which accompany the high $\beta$ equilibria allow penetration with deuteron energies of $\sim 150 \mathrm{keV}$. 


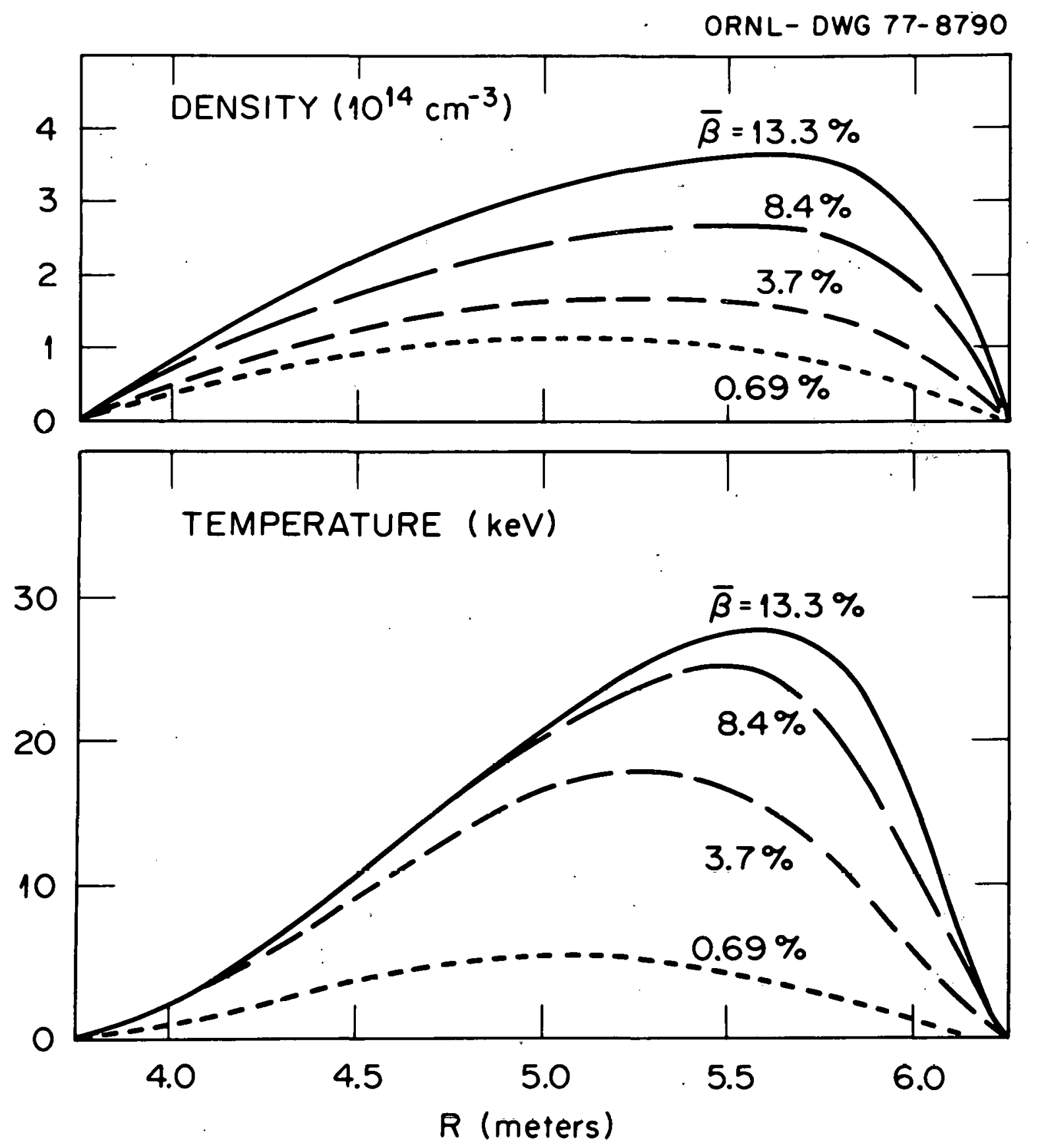

Fig. 6. Temperature and density profiles along the equator as $\beta$ is increased. 


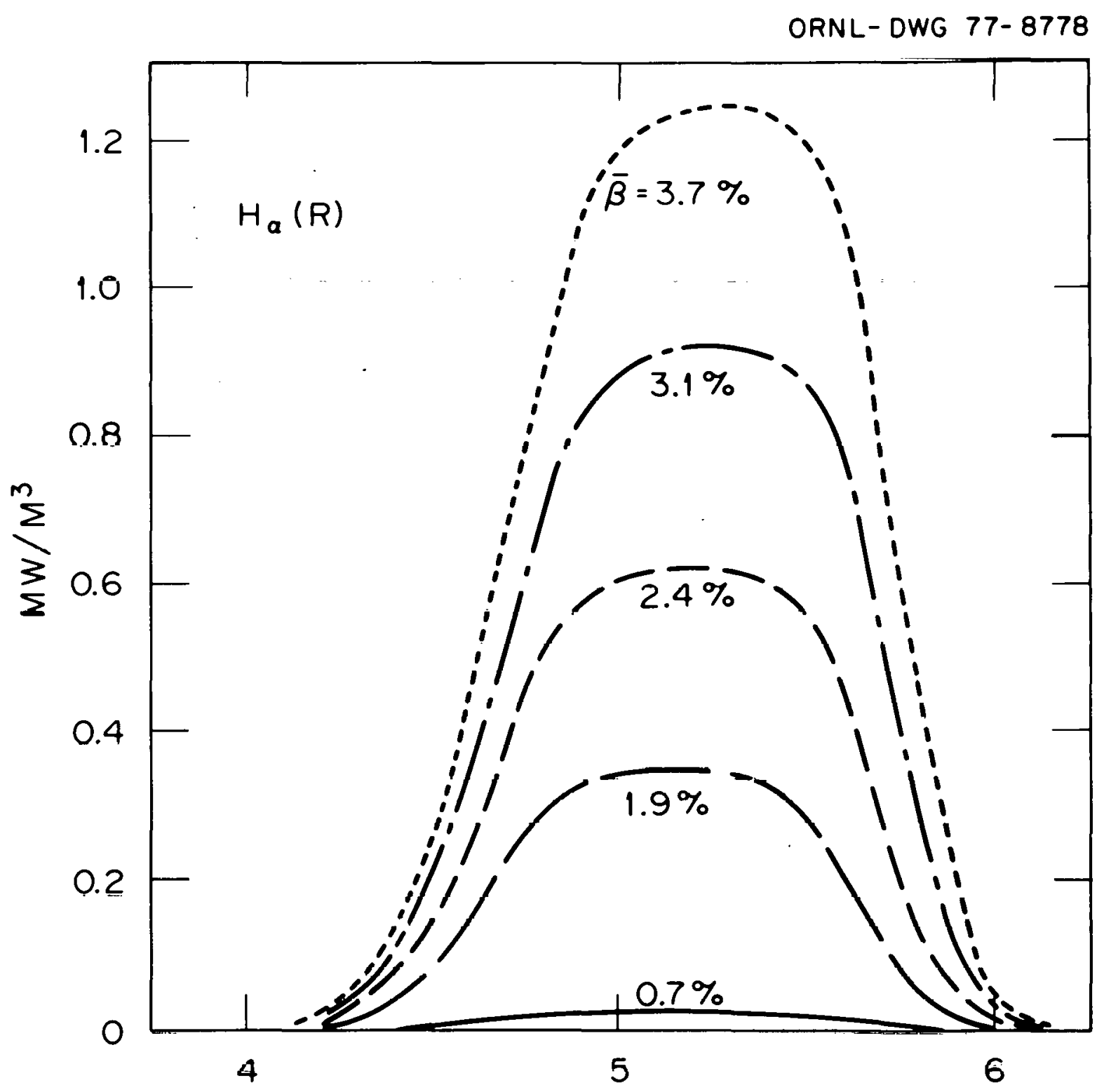

Fig. 7. Increase of $\alpha$-particle heating profiles as $\beta$ increases. 
to increase as $\beta$ increases. Meanwhile, the required injection heating decreases in the center and the profiles can move outward (Fig. 8): These $H(r)$ profiles were obtained by subtracting the $\alpha$-heating profile from the total required power profile, while assuming that the pressure profile, $p(\psi)$, stays unchanged.

When $\bar{\beta} \sim 2 \%$, the $\alpha$-heating in the center begins to, exceed the required beam power. 'At $\bar{B} \sim 3.5 \%$, the central core of the plasma has ignited and beam deposition in that region is not needed. Indeed, if we wish to maintain the $\mathrm{p}(\psi)$ profile, we should discontinue any beam heating in this region.

\section{CONCLUSIONS}

We have shown that heating of TNS must be started at low densities to allow beam penetration. As the plasma is heated and as the density is increased, $\alpha$-heating and flux surface shifts seem to allow adequate penetration with $150-\mathrm{keV}$ deuterons. A simple one-dimensional transport code shows that this model is plausible and that at $\bar{\beta} \sim 3.5 \%$, the $\alpha-$ heating power density has locally exceeded the original beam heating power density and local ignition has occurred. 


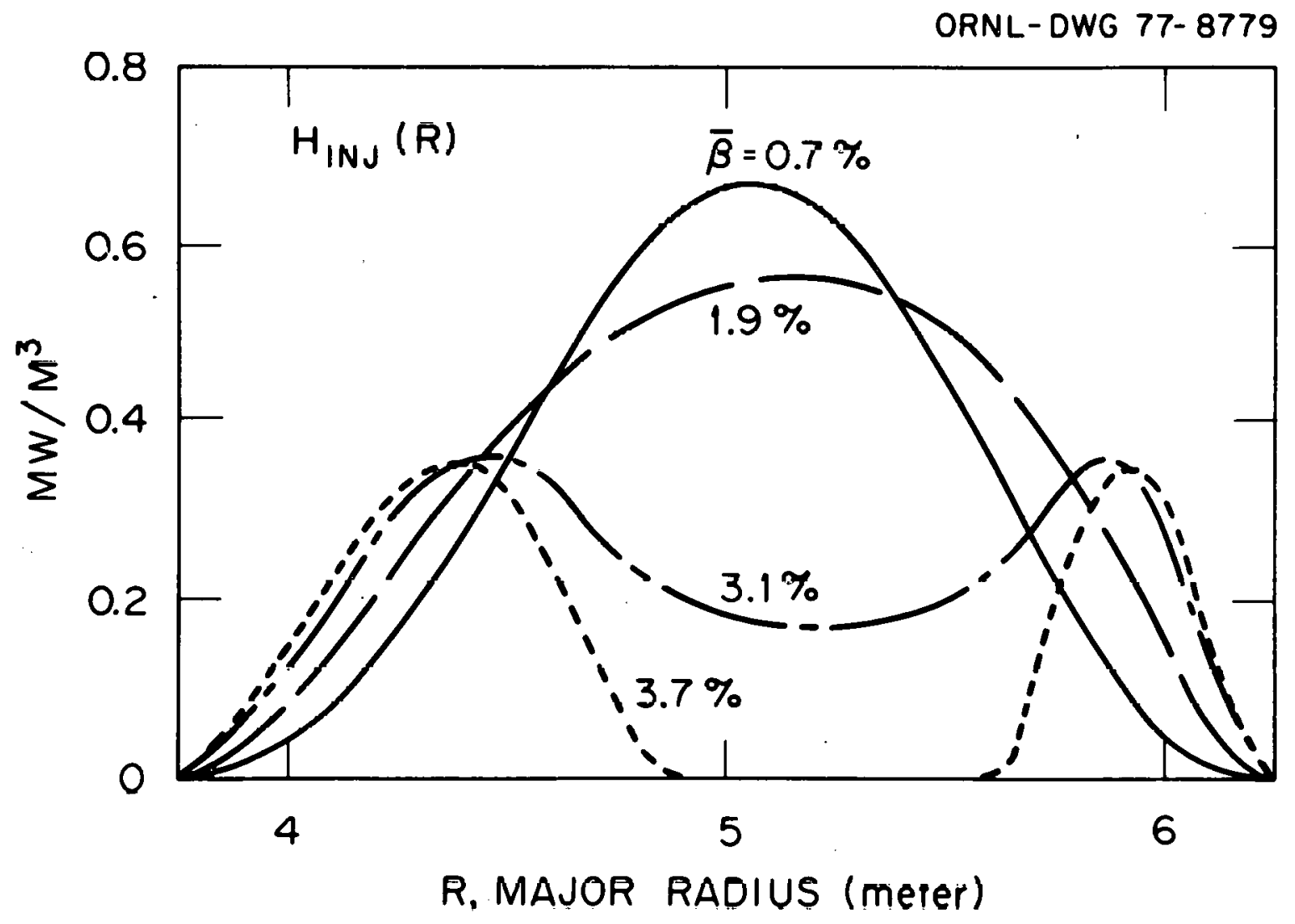

Fig. 8. $H(r)$ profiles showing decrease in required injection heating. 
ORNL/TM-5931

\section{INTERNAL DISTRIBUTION}

$\begin{array}{ll}\text { 1. } & \text { J. K. Ballou } \\ \text { 2. } & \text { W. R. Becraft } \\ \text { 3. } & \text { L. A. Berry. } \\ \text { 4. } & \text { J. D. Callen } \\ \text { 5. } & \text { R. N. Cherdack } \\ \text { 6. } & \text { J. F. Clarke } \\ \text { 7. } & \text { R. A. Dory } \\ \text { 8. } & \text { P. N. Haubenreich } \\ \text { 9. } & \text { G. G. Kelley } \\ \text { 10. } & \text { G. A. Krist } \\ \text { 11. } & \text { J. W. Lue } \\ \text { 12. } & \text { A. T. Mense } \\ 13 . & \text { H. E. McCoy } \\ \text { 14. } & \text { J. R. McNally } \\ 15 . & \text { Y-K. M. Peng } \\ \text { 16-25. M. Roberts } & \text { M. A. Rome } \\ \text { 26-26. } & \text { J. A. }\end{array}$

\author{
47. R. T. Santoro \\ 48. G. Schilling \\ 49. T. E. Shannon \\ 50. P. T. Spampinato \\ 51. N. A. Uckan \\ 52. J. S. Watson \\ 53. W. B. Wood \\ 54. H. T: Yeh \\ 55. ORNL Patent office \\ 56. Laboratory Records - ORNL RC \\ 57-58. Laboratory Records Department \\ 59-60. Central Research Library \\ 61. Document Reference Section \\ 62. Fusion Energy Division \\ Library \\ 63. Fusion Energy Division Reports \\ office
}

EXTERNAL DISTRIBUTION

64. R. W. Conn, Department of Nuclear Engineering, University of Wisconsin, Madison, WI 53706

65. C. A. Flanagan, Westinghouse Electric Corp., Fusion Power Systems Department, P.0. Box 10864, Pittsburgh, PA 15236

66. J. French, Westinghouse Electric Corp., Fusion Power Systems Department, P.0. Box 10864, Pittsburgh, PA 15236

67. G. Gibson, Westinghouse Electric Corp., Fusion Power Systems Department, P.O. Box 10864, Pittsburgh, PA 15236

68. F. M. Heck, Westinghouse Electric Corp., Fusion Power Systems Department, P.0. Box 10864, Pittsburgh, PA 15236

69. Controlled Thermonuclear Research Library, Lawrence Livermore Laboratory, P.N. Box 808, Livermore, CA 94550

70. Q Division Library, Los Alamos Scientific Laboratory, P.0. Box 1663, Los Alamos, NM 87544

71. Controlled Thermonuclear Research Library, c/o Weston M. Stacey, Jr., Argonne National Laboratory, 9700 S. Cass Ave., Argonne, IL 60439

72. CTR Computer Center, c/o Dr. John Killeen, Lawrence Livermore Laboratory, P.0. Box 808, Livermore, CA 94550

73. Librarian, Culham Laboratory, U.K. Atomic Energy Authority, Abingdon, Oxnn, OX14 3DB, United Kingdom

74. Ruth Lengye, Bibliothek, Max-Planck Institut für Plasmaphysik, 8046 Garching bei München, Federal Republic of Germany

75. Library, Centre de Recherches en Physique des Plasmas, 21 Avenue des Bains, 1007, Lausanne, Switzerland

76. A. M. Dupas, Documentation S.I.G.N., Départment de la Physique du Plasma et de la Fusion Controlé, Association EURATOM-CEA sur la Fusion, Centre d'Etudes Nucléaires, BP 85 Centre Du TRI 38041 Grenoble Cedex (France) 
77. Bibliothèque, Service du Confinement des Plasmas, C.E.A., B.P. No. 6, 92, Fontenay-aux-Roses (Seine) France

78. Library, International Centre for Theoretical Physics, Trieste, Italy

79. Library, Laboratorio Gas Ionizzati, Frascati, Italy

80. V. E. Ivanov, Physical-Technical Institute of the Ukranian Academy of Sciences, Sukhumi, U.S.S.R.

81. L. M. Kovrizhnikh, Lebedev Institute of Physics, Academy of Sciences of the U.S.S.R., Leninsky Prospect 53, Moscow, U.S.S.R.

82. Prof. Dshumber G. Lominadze, Academy of Sciences of the Georgian SSR, 8 Dzerzhinski St., 38004, Tbilisi, U.S.S.R.

83. Library, Inst. for Plasma Physics, Nagoya Univ., Nagoya, Japan 464

84. R. Metzinger, Charles Stark Draper Laboratories, 75 Cambridge Parkway, Cambridge, MA 02142

85. D. M. Meade, Plasma Physics Laboratory, Princeton University, P.0. Box 451, Princeron, NJ 08540

86-87. J. 0. Neff, Division of Magnetic Fusion Energy, Mail Stop G-234, Eirelgy Resealch and Develupmenl Admlinlslralluil, Washingcon, It 20545

88. Plasma Physics Library, Plasma Physics Laboratory, Princeton Univ., Forrestal Campus, P.0. Box 451, Princeton, NJ 08540

89. F. B. Marcus, General Atomic Co., P.0. Box 81608, San Diego, CA 92138

90. T. C. Varljen, Westinghouse Electric Corp., Fusion Power Systems Department, P.0. Box 10864, Pittsburgh, PA 15236

91. S. S. Waddle, Energy Research and Development Administration, Oak Ridge Operations, P.O. Box E, Oak Ridge, TN 37830

92. Library, FOM-Institut voor Plasma-Fysica, Rijnhuizen, Jutphaas, Netherlands

93. Plasma Physics Group, Department of Engineering Physics, Australian National University, P.0. Box 4, Canberra A.C.T. 2600, Australia

94. Thermonuclear Library, Japan Atomic Energy Research Institute, Tokai, Naka, Ibarak1, Japan

95. Dr. D. G. McAlees, Exxon Nuclear Co., Inc., Research and Technology Laser Enrichment Department, 2955 George Washington Way, Richland, WA 99352

96. CTR Reading Room, c/o Prof. D. W. Kerst, Dept. of Physics, Sterling Hal1, Univ. of Wisconsin, Madison, WI 53706

97. CTR Reading Room, c/o Prof. I. B. Bernstein, Yale Univ., 200 Mason Laboratory, Dept. of Engineering and Applied Science, New Haven, CT 06510

98. Center for Plasma Physics and Thermonuclear Research, c/o D. W. Ross, Physics Dept., Üniv. of 'l'exas, Austin, 'IX 7871'

99. CTR Reading Room, c/o Prof. B. D. Fried, Physics Dept., Univ. of California, Los Angeles, CA 90024

100. CTR Reading Room, c/o Prof. D. C. Montgomery, Physics and Astronomy Dept., Univ. of Iowa, Iowa City, IA 52240

101. Magneto-Fluid-Dynamics Library, c/o Dr. Harold Grad, Courant Inst. of Math. Sci., New York Univ., 251 Mercer St., New York, NY 10012

102. CTR Reading Room, c/o Prof. Allan N. Kaufman, Physics Dept., Univ. of California, Berkeley, CA 94720 
103. Dr. David A. Dingee, Fusion Programs, Battelle-Northwest, Battelle Boulevard, Richland, WA 99352

104. CTR Reading Room, c/o Prof. C. S. Liu, Dept. of Physics and Astronomy, Univ. of Maryland, College Park, MD 20742

105. CTR Reading Room, c/o Prof. T. Kammash, 103 Research Administration Building, N. Campus, University of Michigan, Ann Arbor, MI 48105

106. CTR Reading Room, c/o Dr. Ravi N. Sudan, Phillips Hall, Cornell University, Ithaca, NY 14850

107. Prof. Marshall N. Rosenbluth, Institute for Advanced Study, Princeton, NJ 08540

108. CTR Reading Room, c/o Prof. R. Gross, Plasma Research Lab., Columbia University, New York, NY 10027

109. CTR Reading Room, c/o Prof. Roy Gould, California Institute of Technology, Mail Stop 116-81, Pasadena, CA 91125

110. Dr. Nicholas A. Krall, Science Applications, Inc:, P.0. Box 2354, 1200 Prospect St., La Jolla, CA 92037

111. CTR Reading Room, c/o Dr. Jay P. Boris, Plasma Physics, Naval Research Laboratory, Washington, DC 20390

112. Professor A. Simon, Dept. of Mechanical and Aerospace Sciences, University of Rochester, Rochester, NY 14627

113. CTR Library, c/o Dr. Alan F. Haught, United Technologies Research Labs, East Hartford, CT. 06108

114. Dr. H. K. Forsen, Exxon Nuclear Co., Inc. 777-106th Avenue, NE, C-000777, Bellevue, WA 98009

115. Dr. George Vahala, Physics Dept., College of William and Mary, Williamsburg, VA 23185

116. Dr. Robert E. Price, Division of Magnetic Fusion Energy, G-234, Energy Research and Development Administration, Washington, DC 20545

117. Dr. R. C. Davidson, Division of Magnetic Fusion Energy, G-234, Energy Research and Development Administration, Washington, DC 20545

118. Dr. Oscar P. Manley, Division of Magnetic Fusion Energy, G-234, Energy Research and Development Administration, Washington, DC 20545

119. Mr. E. E. Kintner, Division of Magnetic Fusion Energy, G-234, Energy Research and Development Administration, Washington, DC 20545

120. Dr. L. D. Pearlstein, L-388, Lawrence Livermore Laboratory, P.0. Box 808, Livermore, CA 94550

121. Dr. J. P. Friedberg, Los Alamos Scientific Laboratory, Los Alamos, NM 87544

122. Dr. David J. Rose, Department of Nuclear Engineering, MIT, Cambridge, MA 02139

123. Dr. Gareth E. Guest, General Atomic Co., P.O. Box 81608, San Diego, CA 92138

124. Dr. Claude Mercier, Service du Theorie des Plasmas, Centre d'Etudes Nucleaires, Fontenay-aux-Roses (Selne) France

125. Dr. J. B. 'l'aylor, Culham Laboratory, UKAEA, Abingdon, Oxon, OX14 3DB, United Kingdom

126. Dr. D. Pfirsch, Institute for Plasma Physics, 8046 Garching bei München, Federal Kepublic of Germany 
127. Dr. V. D. Shafranov, I. V. Kurchatov Inst. of Atomic Energy, 46 Ulitsa Kurchatova, P.0. Box 3402, Moscow, U.S.S.R.

128. Dr. A. Rogister, Institute for Plasma Physics, KFA, Postfach 1913, D-5170, Jilich 1, Federal Republic of Germany

129. Dr. J. G. Cordey, Culham Laboratory, UKAEA, Abingdon, Oxon, OX14 3DB, United Kingdom

130. Dr. David Baldwin, L-388, Lawrence Livermore Laboratory, P.o. Bux 808, Livernore, CA 94550

131. CTR Reading Room, c/o Prof. Bruno Coppi, Dept. of Physics, MIT, Cambridge, MA 02138

132. Dr. Harold P. Furth, Princeton Plasma Physics Laboratory, Princeton University, P.0. Box 451, Princeton, NJ 08540

133. Dr. Paul H. Rucherford, Princeton Plasma Physics Laboratory, Princeton University, P.0. Box 451, Princeton, NJ 08540

134. Dr. Herbert H. Woodson, Department of Electrical Engineering, University of Texas, Austin, TX 78712

135. Research and Technical Support Division, Energy Research and Development Administration, Uak Kidge Uperations, $\bar{P} . \dot{U}$. Bō̄ $E$, Dak Ridge, TN 37830

136-162. Technical Information Center, P.0. Box 62, Oak Ridge, TN 37830 